\title{
Vuorovaikutusosaaminen tutkijoiden työssä
}

ANNE LAAJALAHTI

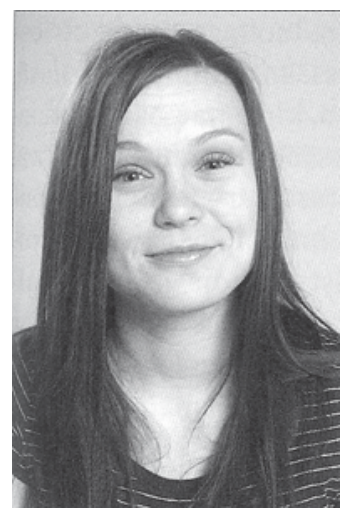

Tutkimusyhteistyö on lisääntynyt, ja tutkimusta tehdään nykyisin aiempaa enemmän ryhmätyönä. Tutkimusongelmien monimutkaistuminen on lisännyt tieteenalojen rajat ylittävää yhteistyötä. Artikkelissa lähestytään tutkijoiden työtä vuorovaikutusosaamisen näkökulmasta kuvaamalla tutkijoiden työlle ominaisen vuorovaikutuksen luonnetta, esittelemällä lähestymistapoja itse vuorovaikutusosaamisen käsitteelle sekä tarkastelemalla vuorovaikutusta tutkijan työssä. Artikkeli pohjautuu valmisteilla olevaan väitöskirjaan, jossa tarkastellaan tutkijoiden kokemuksia vuorovaikutusosaamisesta ja sen kehittymisestä työssään. iestinnällä ja vuorovaikutuksella on keskeinen merkitys tutkijoiden työssä. Ei ole kuitenkaan aivan yksinkertainen kysymys, mitä vuorovaikutusosaaminen on tutkijoiden työssä. Millaisesta ilmiöstä on kyse? Millaista vuorovaikutusosaamista tutkimusta tehtäessä tarvitaan? Millaisista näkökulmista tutkijoiden vuorovaikutusosaamista voidaan tarkastella? Millaisen kontekstin tutkijoiden työ luo vuorovaikutusosaamiselle? Lähestyn artikkelissani näitä kysymyksiä kuvaamalla tutkijoiden työlle ominaisen vuorovaikutuksen luonnetta, esittelemällä erilaisia lähestymistapoja vuorovaikutusosaamisen käsitteeseen sekä pohtimalla vuorovaikutusosaamisen olemusta tutkijoiden työssä.

Vuorovaikutusosaamista on tutkittu jo melko runsaasti esimerkiksi puheviestinnässä, sosiaalipsykologiassa ja kasvatustieteissä (Valkonen 2003, 26-27; Wilson \& Sabee 2003, 3), mutta erityisesti tutkijoiden vuorovaikutusosaamiseen ei ole kiinnitetty merkittävää huomiota. Vuorovaikutusosaamisen tarkastelu tutkijoiden työssä on kuitenkin tärkeää, sillä heidän työnsä edellyttää monipuolista vuorovaikutusosaamista eri alojen asiantuntijoiden välillä sekä kansallisesti että kansainvälisesti. Tutkijoiden vuorovaikutusosaamisella on merkitystä esimerkiksi uuden tiedon tuottamisessa ja tiedon popularisoimisessa, ja tutkijoiden vuo- rovaikutusosaamisen voidaan ajatella olevan laajemminkin yhteydessä tieteellisen tutkimuksen tasoon, sen kansainväliseen kilpailukykyyn, näkyvyyteen ja arvostukseen. Koska tutkimus on teknologisen, taloudellisen ja yhteiskunnallisen kehityksen keskeinen voimavara (Suomen tieteen tila ja taso 2003, 11) ja koska tutkimustietoa tarvitaan myös poliittisen päätöksenteon taustalla, kytkeytyy tutkijoiden vuorovaikutusosaaminen yleisemminkin - joskin välillisesti - yhteiskunnan hyvinvointiin.

Tutkijoiden vuorovaikutusosaamisen tärkeyttä korostaa, että monien lähteiden mukaan tutkimusyhteistyö on lisääntynyt (Poteri 2007, 14; Solomon, Boud, Leontios \& Staron 2001, 275; Ylijoki \& Aittola 2005, 8) ja tutkimusta tehdään nykyisin entistä useammin ryhmätyönä (Hakala, Kaukonen, Nieminen \& Ylijoki 2003, 77; Ylijoki \& Aittola 2005, 16). Muutos koskee myös humanistisia ja yhteiskuntatieteellisiä aloja, joskin niillä tehdään yhä enemmän yksilötyötä kuin luonnontieteissä, lääketieteessä tai tekniikan alalla (Suomen tieteen tila ja taso 2003, 52; Tutkijanuratyöryhmän loppuraportti 2006, 10). Konkreettiseksi esimerkiksi yhteistyön ja ryhmätyön lisääntymisestä käy yhteisartikkeleiden määrän kasvu (Cronin 2004).

Uudet yhteiskunnalliset haasteet ja tutkimusongelmien monimutkaistuminen ovat lisänneet tie- 
teenalojen rajat ylittävää tutkimusyhteistyötä (Suomen tieteen tila ja taso 2003, 52; Ylijoki \& Aittola 2005, 8). Myös monet tiedepolitiikan toimet, esimerkiksi tutkimus- ja teknologiaohjelmat, ovat vaikuttaneet omalta osaltaan uusien, monitieteisten tutkimusalojen syntyyn (Suomen tieteen tila ja taso 2003, 11). Monitieteisen yhteistyön lisäksi kansainvälistyminen on lisännyt tutkijoiden vuorovaikutusosaamisen merkitystä entisestään. Kansainvälisyys on korostunut tutkimustyössä, ja suomalaisten tutkijoiden yhteisjulkaisut ulkomaisten tutkijoiden kanssa ovat lisääntyneet (Ammatiksi tutkija 2005, 2; Suomen tieteen tila ja taso 2003, 83). Lisäksi internet on tehnyt eri maissa työskentelevien tutkijoiden yhteydenpidosta helpompaa, nopeampaa ja halvempaa.

Muutos vuorovaikutuksen määrässä ei koske kuitenkaan vain tutkijoiden välistä ja tieteensisäistä kehitystä, vaan dialogisuuden lisääntymisestä on havaintoja myös tutkijoiden ja muiden yhteiskunnallisten toimijoiden sekä kansalaisten välillä (Phillips 2006, 233-244). Vuorovaikutuksen lisääntyminen tieteenalojen sisällä ja välillä sekä eri sidosryhmien kanssa luo uudenlaisia haasteita tutkijoiden vuorovaikutusosaamiselle ja tekee siitä sekä olennaisen että mielenkiintoisen tutkimuskohteen.

\section{Vuorovaikutus tutkijoiden työssä}

Tutkijoiden työtä pidetään usein hyvin yksinäisenä ja itsenäisenä. Todellisuudessa tutkijat kuitenkin työskentelevät monimutkaisissa toimintaympäristöissä ja tutkimuksen tekeminen on hyvin sosiaalista. Tutkijat toimivat työssään monenlaisten tahojen kanssa: he ovat vuorovaikutuksessa esimerkiksi oman ja muiden tieteenalojen tutkijoiden, perus- ja jatkotutkinto-opiskelijoiden, poliitikkojen ja muiden päätöksentekijöiden sekä elinkeinoelämän, erilaisten sidosryhmien ja tiedotusvälineiden edustajien kanssa.

Vaikka tutkimustyötä leimaa aina toki jollain tapaa itsenäisyyden vaatimus (Ammatiksi tutkija 2005, 2), tutkimusta tehdään usein ryhmissä ja vuorovaikutuksella muiden tutkijoiden kanssa on keskeinen merkitys tieteellisessä luovuudessa, uuden tiedon tuottamisessa sekä uusien ajatusten syntymisessä ja testaamisessa (Levine \& Moreland 2004, 164; Wasser \& Bresler 1996, 5). Lisäksi vuorovaikutuksen nostaa keskiöön se, että tutkimustulokset otetaan usein vakavasti vasta vertaisarvioinnin jälkeen (Levine \& Moreland 2004,
164). Tutkijoiden on siis ratkaisevan tärkeää olla vuorovaikutuksessa muiden kanssa ja sitä kautta laajentaa osaamistaan sekä levittää tutkimustuloksiaan tieteellisen yhteisön ja muiden tutkimus- ja innovaatioympäristön toimijoiden käyttöön.

Tutkijat kohtaavat työssään monenlaisia tilanteita ja tehtäviä, joissa viestintä ja vuorovaikutus ovat erityisen keskeisessä asemassa. Tutkijat törmäävät moniin viestintään ja vuorovaikutukseen liittyviin haasteisiin muun muassa osallistuessaan tieteelliseen keskusteluun, tuottaessaan ja etsiessään tietoa, työskennellessään tutkimusryhmissä, projekteissa ja hankkeissa, kirjoittaessaan yhteisartikkeleita sekä kerätessään tutkimusaineistoa. Viestintää ja vuorovaikutusta tarvitaan myös esimerkiksi konferenssiesitelmiä pitäessä, verkostoituessa, etsittäessä yhteistyötahoja ja neuvoteltaessa heidän kanssaan, popularisoitaessa tietoa ja kohdatessa poliittisten päätösten tekijöitä sekä tiedotusvälineiden ja elinkeinoelämän edustajia. Viestinnän ja vuorovaikutuksen osuutta ei voida vähätellä - ajateltiinpa sitten pelkästään tutkimustyötä tai laajemminkin tutkijoiden työtä, jolloin etenkin varttuneiden tutkijoiden ammatinkuvaan voi kuulua myös monenlaisia muita asiantuntijatehtäviä, hallinnollisia ja tiedepoliittisia tehtäviä, johtamis- ja esimiestyötä sekä opettamista ja ohjaamista.

Tutkijoiden työlle tyypillisestä vuorovaikutuksesta voidaan erottaa erilaisia ulottuvuuksia riippuen siitä, kenen kanssa tutkijat ovat vuorovaikutuksessa. Kiikerin ja Ylikosken (2004) mukaan omasta tutkimusaiheesta puhumisen tavat eroavat esimerkiksi sen mukaan, puhutaanko saman tutkimusaiheen parissa työskenteleville tutkijoille, tutkijoille oman erityisalan ulkopuolella tai muilla tieteenaloilla, tieteenalan opiskelijoille, poliitikoille ja muille päätöksentekijöille, toimittajille vai kansalaisille. He erottavat tutkijoiden työstä vertaiskommunikaation ja popularisoivan kommunikaation ulottuvuuden ja sijoittavat edelliset yleisöt näistä syntyvälle jatkumolle. Vertaiskommunikaatiolle on heidän mukaansa ominaista omasta tutkimusaiheesta keskusteleminen, kun taas popularisoivaa kommunikaatiota leimaa pikemminkin omasta tutkimusaiheesta kertomisen aspekti. (Kiikeri \& Ylikoski 2004, 188-190.) Vaikka Kiikerin ja Ylikosken ajatus ehkä yksinkertaistaakin liikaa vuorovaikutuksen olemusta, auttaa se sellaisenaan hahmottamaan tutkijoiden kohtaamien viestintä- ja vuorovaikutustilanteiden monimuotoisuutta. 
Tutkijoiden työhön sisältyy kaiken kaikkiaan monenlaista vuorovaikutusta, mutta millaista vuorovaikutusosaamista nämä tutkijoiden työlle ominaiset vuorovaikutustilanteet ja -suhteet oikein edellyttävät? On huomattava, että edellä esitetty kuvaus auttaa ymmärtämään, missä ja mihin vuorovaikutusosaamista tarvitaan, mutta ei vielä sellaisenaan vastaa kysymykseen, mitä vuorovaikutusosaaminen itse asiassa on (ks. lisäksi Hargie \& Dickson 2004, 4). Millaisesta ilmiöstä vuorovaikutusosaamisessa on oikein kysymys? Miten tutkijoiden vuorovaikutusosaamista tulisi lähestyä?

Esittelen seuraavaksi erilaisia vuorovaikutusosaamisen jäsennystapoja, jonka jälkeen tarkastelen vuorovaikutusosaamista nimenomaan tutkijoiden työn näkökulmasta.

\section{Lähestymistapoja vuorovaikutusosaa- misen käsitteeseen}

Vuorovaikutusosaamisen käsite on kaiken kaikkiaan monimerkityksinen. Tilannetta hankaloittaa, että kirjallisuudessa viitataan ihmisten väliseen kanssakäymiseen liittyvään osaamiseen monilla eri käsitteillä. (Ks. esim. Laajalahti 2007, 336; Spitzberg \& Cupach 2002, 574.) Tällaisia ovat esimerkiksi viestintä- ja vuorovaikutusosaaminen sekä sosiaalinen, relationaalinen ja interpersonaalinen kompetenssi. Käsitteiden välille voidaan toki tehdä perustellusti eroja, mutta niitä käytetään usein synonyymisesti tai jokseenkin sekavasti. Myös taitojen käsitettä käytetään usein osaamisen synonyymina, vaikka osaamisen katsotaankin useimmiten olevan taitoja laajempi käsite (Valkonen 2003, 25-28).

Lukuisista määrittely-yrityksistä huolimatta tutkijat eivät ole päässeet yksimielisyyteen siitä, mitä vuorovaikutusosaaminen lopulta on (Wilson \& Sabee 2003, 35). Koska vuorovaikutusosaamista on jo tutkittu runsaasti monenlaisissa työ- ja yksityiselämän konteksteissa, erilaisten teoreettisten näkökulmien ja metodologisten lähestymistapojen valikoima on laaja ja moninainen. Seuraava koonti tarjoaa kuvan siitä tarkastelutapojen kirjosta, josta käsin ihmisten väliseen vuorovaikutukseen liittyvää osaamista on lähestytty.

Vuorovaikutusosaamisen sijainti. Vuorovaikutusosaamista voidaan lähestyä joko käyttäytymisenä, jolloin osaaminen näyttäytyy toimivan subjektin ominaisuutena, tai käyttäytymisestä syntyneenä vaikutelmana, jolloin osaaminen sijaitsee pikemminkin arvioijan mielessä. Vuorovaikutusosaamisen voidaan ajatella olevan yksilötason sijaan myös suhdetason ilmiö, jolloin vuorovaikutusosaamisen ei ajatella sijaitsevan yksilöissä itsessään vaan rakentuvan vuorovaikutussuhteen osapuolten välisessä toiminnassa ja ilmenevän vuorovaikutuksen suhdetasolla. (Spitzberg 2000, 109-114.)

\section{Vuorovaikutusosaamisen piirretyyppisyys ja} tilannekohtaisuus. Tutkimuskirjallisuudessa ollaan erimielisiä siitä, miten paljon yksilön vuorovaikutusosaaminen voi muuttua ajan myötä. Osa pitää osaamista suhteellisen pysyvänä luonteenlaatuna tai piirteenä, joka harvoin vaihtelee. Osa näkee osaamisen taas kytkeytyvän tilanteeseen ja vaihtelevan esimerkiksi viestintäkumppaneiden ja tavoitteiden mukaan. (Parks 1994, 591-592; Rubin 1990, 103-104; Rubin, Graham \& Mignerey 1990, 1; Spitzberg \& Cupach 1984, 85-93.)

Kenelle syntynyt vaikutelma? Jos päädytään ajattelemaan, että mikään viestintäkäyttäytyminen ei ole sinällään kompetenttia vaan että sellaiseksi sen tekee vasta jonkun tilannekohtainen tulkinta, on tärkeää huomioida, kenen tekemästä arviosta on kysymys. Vuorovaikutusosaamista voidaan lähestyä esimerkiksi viestijän itsensä, vuorovaikutustilanteen toisen osapuolen, ulkopuolisen arvioijan tai tutkijan tekemänä tulkintana, ja osaamisen tasoa voidaan mitata myös monenlaisilla mittareilla. Koska eri lähteet arvioivat saman toiminnan useimmiten hieman eri lailla, ei ole kuitenkaan aivan yksinkertaista päättää, kenelle syntyneeseen vaikutelmaan osaamisen määrittely tulisi kulloinkin perustaa. (Parks 1994, 590-591; Spitzberg 2000, 113; Spitzberg \& Brunner 1991, 32; Wilson \& Sabee $2003,15$.

Vuorovaikutusosaamisen ulottuvuudet. Vuorovaikutusosaamista lähestytään usein jäsentämällä sen eri ulottuvuuksia, ja vuorovaikutusosaamisesta erotetaan monesti kognitiivinen, behavioraalinen ja affektiivinen ulottuvuus. Toisin sanoen vuorovaikutusosaamisen katsotaan usein koostuvan tiedosta, taidosta ja motivaatiosta. Toisinaan myös metakognitiivisen toiminnan taso erotetaan omaksi osaamisen ulottuvuudekseen. (Rubin 1990, 109-112; Spitzberg 2006, 6-7; Valkonen 2003, 35-38.) Osaamisen ulottuvuudet ovat tiiviisti yhteydessä toisiinsa ja erotettavissa vain teoreettisella tasolla (Valkonen 2003, 39), vaikkakin useis- 
sa tutkimuksissa on keskitytty määrittelemään ja luokittelemaan erityisesti vuorovaikutustaitoja (Almeida 2004, 358; Spitzberg 2000, 104).

Vuorovaikutusosaamisen kriteerit. Toinen yleinen kirjallisuudessa esiintyvä jäsennystapa on niiden kriteerien eritteleminen, joilla viestintä- ja vuorovaikutuskäyttäytymistä voidaan arvioida. Vuorovaikutusosaamisen kriteereiksi on esitetty esimerkiksi tarkkuutta, tyytyväisyyttä, todellisuudentuntua ja eettisyyttä. Ylivoimaisesti yleisimmät kirjallisuudessa esiintyvät kriteerit ovat kuitenkin tehokkuus ja tarkoituksenmukaisuus. Tehokkuudella tarkoitetaan sitä, miten hyvin vuorovaikutustilanteen osapuolet saavuttavat tavoitteitaan. Tarkoituksenmukaisuudella viitataan puolestaan siihen, miten sopivaa ja sosiaalisesti hyväksyttävää vuorovaikutuskäyttäytyminen kussakin tilanteessa on. (Spitzberg 2000, 104-109; 2003, 97-98; Spitzberg \& Cupach 2002, 575-583; Valkonen 2003, 145-148.)

Vuorovaikutusosaamista voidaan lähestyä myös työelämän kvalifikaatiovaatimuksena. Esimerkiksi Kostiaisen (2003, 30-34) väitöskirjaan on koottu erilaisia tapoja, miten vuorovaikutusosaamista on jäsennetty kirjallisuudessa osaksi ammattitaitoa kuvaavia luokituksia. Kompetenssitutkimusta on tehty käyttäen tarkastelutasona niin yksilöä, ryhmää kuin organisaatiota (Jablin \& Sias 2001), ja toisinaan vuorovaikutusosaamista on analysoitu laajemminkin yksilön yhteiskuntasuhteen ja yhteiskunnallisen toimijuuden näkökulmasta (Valkonen 2003, 27). Vuorovaikutusosaamista on lähestytty kirjallisuudessa myös osana erilaisia viestintäteorioita (ks. esim. Wilson \& Sabee 2003) sekä esimerkiksi kontrollin, yhteistyön ja sopeutumisen näkökulmasta (Parks 1994, 592595; Spitzberg \& Cupach 1989, 17-24). Koska ihmisten väliseen kanssakäymiseen liittyvä osaaminen on hyvin monipuolinen ilmiö, kaikkien kirjallisuudessa esiintyvien lähestymistapojen kokoaminen tähän yhteyteen ei ole kuitenkaan mahdollista.

Vuorovaikutusosaamisen kontekstuaalisuus. Vuorovaikutusosaamista on tarkasteltu myös pohtimalla vuorovaikutusosaamisen ja kontekstin välisiä yhteyksiä (ks. esim. Rubin 1990, 103-104). Usein on esitetty melko yksioikoisesti, että vuorovaikutusosaaminen on kontekstuaalista (ks. esim. Spitzberg 2003, 118; Spitzberg \& Brunner
1991, 28; Spitzberg \& Cupach 2002, 583). Koska konteksti ja vuorovaikutusosaaminen ovat monimerkityksisiä käsitteitä, joita voidaan lähestyä monella eri tavalla ja monella eri tasolla, tämänkaltainen väite jää kuitenkin hämäräksi, ellei ensin määritellä, mitä näillä käsitteillä tarkoitetaan.

Vuorovaikutusosaamisen kontekstuaalisuutta lähestytään valitettavan usein joko-tai-kysymyksenä, vaikka eri tavoin käsitteitä tarkastelemalla vuorovaikutusosaaminen voidaan nähdä oikeutetusti sekä kontekstuaalisena että dekontekstuaalisena ilmiönä. Vuorovaikutusosaamisen voidaan esittää olevan kontekstuaalista esimerkiksi silloin, kun sitä lähestytään käyttäytymisen sijaan vuorovaikutustilanteessa syntyneenä vaikutelmana. Kontekstuaaliset seikat (mm. aika, kulttuuri, viestintätilanne ja -suhde) vaikuttavat aina osaamisesta tehtäviin päätelmiin, ja eri ihmiset pitävät eri käyttäytymistä kompetenttina eri konteksteissa (Spitzberg 2006, 5; Spitzberg \& Brunner 1991, 32). Myös tehokkuuden ja tarkoituksenmukaisuuden kriteerit määrittyvät aina kontekstista käsin, ja se, mikä on tehokasta tai tarkoituksenmukaista toisessa kontekstissa, ei ole sitä välttämättä toisessa (Rubin 1990, 109; Spitzberg \& Cupach 1984, 109).

Vuorovaikutusosaamisen voidaan sen sijaan katsoa olevan dekontekstuaalista esimerkiksi silloin, kun sitä tarkastellaan luonteenpiirteisiin kytkeytyvän viestintäarkuuden näkökulmasta. McCroskeyn $(1998,6)$ mukaan yksilön luonteenpiirteisiin - olivatpa ne sitten synnynnäisiä tai opittuja - liittyvä viestintäkäyttäytyminen on usein melko yhtenäistä kontekstista toiseen.

Vuorovaikutusosaamisessa voi siis tästä näkökulmasta katsoen olla jotain pysyvää vuorovaikutustilanteesta ja -suhteesta toiseen: toisilla saattaa esimerkiksi olla suurempi taipumus viestintäarkuuteen kuin toisilla.

\section{Tutkijoiden työ vuorovaikutusosaami- sen kontekstina}

Tutkijoiden työ muodostaa vuorovaikutusosaamisen tutkimiselle moniulotteisen ja vivahteikkaan kontekstin, jota voidaan jäsentää monenlaisten kontekstuaalisten ulottuvuuksien suhteen. Tutkijoiden työstä voidaan erottaa esimerkiksi erilaisia suhde- ja tilannetasoon, kulttuuriin sekä käytettäviin viestintävälineisiin liittyviä kontekstuaalisia aspekteja.

Esimerkiksi tutkijoiden keskinäistä tai vaikkapa tutkijan ja tiedetoimittajan välistä vuorovaikutus- 
suhdetta voidaan lähestyä yhtenä tutkijoiden työn kontekstuaalisena ulottuvuutena (suhdeulottuvuus). Samaan tapaan voidaan lähestyä vaikkapa posteriesitelmää ja tutkimushaastattelua (tilanneulottuvuus) tai eurooppalaista ja yhdysvaltalaista tutkimustraditiota edustavien tutkijoiden työtä (kulttuuritaustan ulottuvuus). Myös sen, ollaanko vuorovaikutuksessa kasvokkain vai erilaisten viestintätekniikoiden välityksellä, voidaan ajatella luovan tutkimustyölle omat kontekstuaaliset erityispiirteensä (viestintävälineen ulottuvuus).

Tutkijoiden työ ei ole selvärajainen ja yksioikoinen konteksti, vaan sen tarkastelussa tulee ottaa huomioon, puhutaanko tutkimuksen tekemisestä esimerkiksi yritysmaailmassa vai yliopistossa ja keskitytäänkö esimerkiksi luonnontieteellisellä vai humanistisella alalla tehtävään tutkimukseen. Eri tieteenalat poikkeavat toisistaan niin teorioiden ja metodien kuin vuorovaikutusmuotojen ja julkaisutapojen suhteen (Hakala, Kaukonen, Nieminen \& Ylijoki 2003, 77), ja sillä, millaisella kontekstin tasolla liikutaan ja mistä näkökulmasta tutkijoiden työtä tarkastellaan, on vaikutusta myös siihen, millaisena vuorovaikutusosaaminen näyttäytyy.

Tutkijoiden vuorovaikutusosaamista voidaan lähestyä esimerkiksi tutkijan kokemuksena omasta kyvykkyydestään toimia erilaisissa vuorovaikutustilanteissa, vuorovaikutussuhteiden tasolla ilmenevänä ja vuorovaikutukseen osallistuvien yhdessä tuottamana kvaliteettina tai vaikkapa tutkijoiden välisen yhteistyön mahdollistavana ammattiosaamisen ulottuvuutena. Vuorovaikutusosaamista voidaan tarkastella myös esimerkiksi tutkijakollegalle syntyneenä vaikutelmana kollegan tavasta toimia eri sidosryhmien kanssa käytävissä neuvotteluissa, mittarilla mitattavissa olevana vuorovaikutuksen tehokkuutena ja tarkoituksenmukaisuutena kansainvälisessä tutkimusyhteistyössä, tutkimusryhmän johtajan kykynä sitouttaa tutkimusryhmän jäsenet tai vaikkapa konferenssiesitelmää pitävän tutkijan taitona argumentoida, vakuuttaa muut paikalla olijat ja osallistua tieteelliseen keskusteluun.

Valitusta tarkastelutasosta tietoisena oleminen on tärkeää, sillä vuorovaikutusosaamisen erilaiset hahmottamistavat vaikuttavat monella tapaa myös aikuiskasvatuksen käytäntöihin. Se, millaisia attribuutioita vuorovaikutusosaamiselle annetaan ja missä vuorovaikutusosaamisen hahmotetaan sijaitsevan, vaikuttaa esimerkiksi käsityksiin siitä, mitä vuorovaikutusosaamisesta tulisi opettaa, mikä on ylipäänsä opittavissa ja mihin vuorovaikutusosaamisen arvioinnissa tulisi ensisijaisesti kiinnittää huomiota.

\section{Lopuksi}

Tutkimustieto on keskeinen osa yhteiskunnan kehitystä, kilpailukykyä ja hyvinvointia. Koska tutkimuksen menestyksellinen tekeminen edellyttää vuorovaikutusta, tulisi tutkijoiden työtä tarkastella jatkossa lähemmin vuorovaikutusosaamisen näkökulmasta.

Tutkijoiden vuorovaikutusosaamista ei tulisi nähdä ainoastaan hyödyllisenä välineenä saavuttaa tutkimustyölle asetettuja tavoitteita tai välittää tutkimustyön tuloksia eteenpäin. Sen sijaan tulisi ymmärtää, että viestintä ja vuorovaikutus ovat jo itsessään tutkijan työtä. (Ks. lisäksi Laajalahti 2007, 341.)

Tutkijoiden vuorovaikutusosaamista voidaan jäsentää jo olemassa olevan ymmärryksen perusteella. Voidaankin sanoa, että tutkijat tarvitsevat työssään esimerkiksi tietoa vuorovaikutusstrategioista, -prosesseista ja -normeista ja monenlaisia puhumiseen ja kuuntelemiseen sekä muuhun ilmaisu- ja havaintotoimintaan liittyviä taitoja, jotka mahdollistavat heidän toimimisensa erilaisissa esiintymis- ja ryhmätyötilanteissa. Lisäksi tutkijat tarvitsevat motivaatiota viestiä ja olla vuorovaikutuksessa eri toimijoiden kanssa tavalla, jota voidaan pitää tehokkaana ja tarkoituksenmukaisena.

Vuorovaikutusosaamisen luonteen lisäksi tarvitaan kuitenkin lisää tutkimusta siitä, millaisia merkityksiä tutkijat itse antavat vuorovaikutusosaamiselle työssään ja miten vuorovaikutusosaaminen kehittyy informaalisti työssä oppimalla. Tämänkaltaista tietoa tarvitaan, jotta voitaisiin tukea tutkijoiden työssä oppimista ja luoda toimintaympäristöjä, joissa tutkijoilla olisi mahdollisuus kehittää tieteellisen kompetenssin lisäksi myös vuorovaikutusosaamistaan. Tietoa vuorovaikutusosaamiseen liittyvistä merkityksenannoista ja oppimiskokemuksista voitaisiin hyödyntää myös tutkijakoulutuksen kehittämisessä.

\section{Lähteet}

Almeida, E. P. (2004). A discourse analysis of student perceptions of their communication competence. Communication Education, 53 (4), 357-364. 
Ammatiksi tutkija. (2005). Näkökulmia tutkijan työhön. Helsinki: Suomen Akatemia.

Cronin, B. (2004). Bowling alone together: academic writing as distributed cognition. Journal of the American Society for Information Science and Technology 55 (6), 557-560.

Hakala, J., Kaukonen, E., Nieminen, M. \& Ylijoki, O.-H. (2003). Yliopisto - tieteen kehdosta projektimyllyksi? Yliopistollisen tutkimuksen muutos 1990-luvulla. Helsinki: Gaudeamus.

Hargie, O. \& Dickson, D. (2004). Skilled interpersonal communication: research, theory, and practice. 4. painos. London: Routledge.

Jablin, F. M. \& Sias, P. M. (2001). Communication competence. Teoksessa F. M. Jablin \& L. L. Putnam (toim.) The new handbook of organizational communication. Thousand Oaks: Sage, 819-864.

Kiikeri, M. \& Ylikoski, P. (2004). Tiede tutkimuskohteena: filosofinen johdatus tieteentutkimukseen. Helsinki: Gaudeamus.

Kostiainen, E. (2003). Viestintä ammattiosaamisen ulottuvuutena. Jyväskylän yliopisto. Jyväskylä Studies in Humanities 1.

Laajalahti, A. (2007). The development of interpersonal communication competence at work. Teoksessa N. Carpentier, P. PruulmannVengerfeldt, K. Nordenstreng, M. Hartmann, P. Vihalemm, B. Cammaerts \& H. Nieminen (toim.) Media technologies and democracy in an enlarged Europe: the intellectual work of the 2007 European media and communication doctoral summer school. The researching and teaching communication series 3. Tartu: Tartu University Press, 335-345.

Levine, J. M. \& Moreland, R. L. (2004). Collaboration: the social context of theory development. Personality and Social Psychology Review 8 (2), 164-172.

McCroskey, J. C. (1998). Why we communicate the ways we do: a communibiological perspective. The Carroll C. Arnold Distinguished Lecture. Presented at the annual convention of the National Communication Association. Chicago, Illinois, November 20, 1997. Boston: Allyn and Bacon.

Parks, M. R. (1994). Communicative competence and interpersonal control. Teoksessa M. L. Knapp \& G. R. Miller (toim.) Handbook of in- terpersonal communication. 2. painos.

Thousand Oaks: Sage, 589-618.

Phillips, L. (2006). Communicating social scientific knowledge dialogically: participatory approaches to communication analysis and practice. Teoksessa N. Carpentier, P. Pruulmann-Vengerfeldt, K. Nordenstreng, M. Hartmann, P. Vihalemm \& B. Cammaerts (toim.) Researching media, democracy and participation: the intellectual work of the 2006 European media and communication doctoral summer school. The researching and teaching communication series 1 . Tartu: Tartu University Press, 233-247.

Poteri, E. (2007). Collaborative information behaviour: a case study of two research groups. Lisensiaatintyö. Digitaalisen viestinnän lisensiaattiohjelma, Viestintätieteiden yliopistoverkosto. Turku: Åbo Akademi.

Rubin, R. B. (1990). Communication competence. Teoksessa G. M. Phillips \& J. T. Wood (toim.) Speech communication: essays to commemorate the 75th anniversary of the Speech Communication Association. Carpondale: Southern Illinois University Press, 94-129.

Rubin, R. B., Graham, E. E. \& Mignerey, J. T. (1990). A longitudinal study of college students' communication competence. Communication Education 39 (1), 1-14.

Solomon, N., Boud, D., Leontios, M. \& Staron, M. (2001). Researchers are learners too: collaboration in research on workplace learning. Journal of Workplace Learning 13 (7/8), 274-281.

Spitzberg, B. H. (2000). What is good communication? Journal of the Association for Communication Administration 29 (1), 103-119.

Spitzberg, B. H. (2003). Methods of interpersonal skill assessment. Teoksessa J. O. Greene \& B. R. Burleson (toim.) Handbook of communication and social interaction skills. Mahwah: Lawrence Erlbaum, 93-134.

Spitzberg, B. H. (2006). CSRS: the conversational skills rating scale. An instructional assessment of interpersonal competence. Paper presented at the annual convention of the National Communication Association. San Antonio, Texas, November 16-19, 2006.

Spitzberg, B. H. \& Brunner, C. C. (1991). Toward a theoretical integration of context and com- 
petence inference research. Western Journal of Speech Communication 55 (1), 28-46.

Spitzberg, B. H. \& Cupach, W. R. (1984). Interpersonal communication competence. Beverly Hills: Sage.

Spitzberg, B. H. \& Cupach, W. R. (1989). Handbook of interpersonal competence research. New York: Springer-Verlag.

Spitzberg, B. H. \& Cupach, W. R. (2002). Interpersonal skills. Teoksessa M. L. Knapp \& J. A. Daly (toim.) Handbook of interpersonal communication. 3. painos. Thousand Oaks: Sage, 564-611.

Suomen tieteen tila ja taso. (2003). Katsaus tutkimustoimintaan ja tutkimuksen vaikutuksiin 2000-luvun alussa. Suomen Akatemian julkaisuja 9/03. Helsinki: Suomen Akatemia.

Tutkijanuratyöryhmän loppuraportti. (2006). Opetusministeriön työryhmämuistioita ja selvityksiä 2006:13. Helsinki: Opetusministeriö.
Valkonen, T. (2003). Puheviestintätaitojen arviointi: näkökulmia lukiolaisten esiintymisja ryhmätaitoihin. Jyväskylän yliopisto. Jyväskylä Studies in Humanities 7.

Wasser, J. Davidson \& Bresler, L. (1996). Working in the interpretive zone: conceptualizing collaboration in qualitative research teams. Educational Researcher 25 (5), 5-15.

Wilson, S. R. \& Sabee, C. M. (2003). Explicating communicative competence as a theoretical term. Teoksessa J. O. Greene \& B. R. Burleson (toim.) Handbook of communication and social interaction skills. Mahwah: Lawrence Erlbaum, 3-50.

Ylijoki, O.-H. \& Aittola, H. (2005). Johdanto: hyvää akateemista työtä etsimässä. Teoksessa H. Aittola \& O.-H. Ylijoki (toim.) Tulosohjattua autonomiaa: akateemisen työn muиttuvat käytännöt. Helsinki: Gaudeamus, 7-17. 